\title{
Identification of Somatomedin/Insulin-Like Growth Factor Immunoreactive Cells in the Human Fetus
}

\author{
VICTOR K. M. HAN, DAVID J. HILL, ALASIAIR J. STRAIN. ANDREW C. TOWI.E.
} JFAN M. I.AUDER. LOUIS F. UNIDERWOOD. AND A. JOSEPH D’ERCOII:

Departments of Pediatrics /V.K.M.H.. I.I.L., A.J.D.J and Anatomy /.1.C.T., J.M1.I... The Lniversity of Worth Carolina. (hapel Hill. N ('27514, and Department of Paediatrics ID.J.H. A.J.S./. The Liviversity of Sheffield. Northern (ieneral Hospital, Sheffield. S57.1T: England

\begin{abstract}
ABSTRACI. Somatomedins/insulin-like growth factors (Sm/IGFs) are present in blood and in extracts from multiple tissues of the human fetus and induce the proliferation of cultured human fetal cells. To identify the cellular location of immunoreactive $\mathrm{Sm} / \mathrm{IGF}$ in human fetal tissues, we have performed immunocytochemistry in tissues from prostaglandin-induced human fetal abortuses of 12 to 20 wk in gestation. Every tissue studied except the cerebral cortex contains $\mathrm{Sm} / \mathrm{IGF}$ immunoreactive cells. Cells staining positively include hepatocytes, hepatic hemopoietic cells, columnar epithelia of the pulmonary airways, intestine and kidney tubules, adrenal cortical cells, dermal cells, skeletal and cardiac muscle fibers, and pancreatic islet and acinar cells. Immunostaining was specific for $\mathrm{Sm} / \mathrm{IGFs}$, but because of the cross-reactivity of the antibodies it was not possible to determine whether the immunoreactivity represented Sm-C/IGF I, IGF II, or both. Liver contained the greatest proportion of immunoreactive cells, while the thymus and spleen had only a few immunostained cells. With the possible exception of dermal and some adrenal cortical cells, the immunoreactive cells do not appear to be the primary sites of $\mathrm{Sm} / \mathrm{IGF}$ synthesis, because parallel in situ hybridization histochemical studies using Sm/IGF oligodeoxyribonucleotide probes show that $\mathrm{Sm} / \mathrm{IGF}$ mRNAs are localized predominantly to fibroblasts and mesenchymal cells. Therefore the immunoreactive cells identified in this study may define sites of action of Sm/IGFs. (Pediatr Res 22: 245-249, 1987)
\end{abstract}

Abbreviations

Sm, somatomedin

IGF, insulin-like growth factor

Sm-C/IGF I, somatomedin-C/insulin-like growth factor I

ICF II, insulin-like growth factor II

GII, growth hormone

NGF, nerve growth factor

PBS, phosphate-buffered saline

BSA, bovine serum albumin

$\mathrm{RBC}$, red blood cells

Received January 26, 1987: accepted March 27.1987.

Correspondence A. Joseph D)Frcole, M.D., Department of Pediatrics. 509 Clinical Sciences Building 229H, The University of North Carolina, ('hapel Hill N('27514

Supported by (irant HD-08299 from the USPHS basic rescarch (irant 1-758 from the March of Dimes National Birth Defect loundation. Birthright. Smith Kline Foundation, and the Yorkshire (ancer Research (ampaign. V.K.M.H is a recipient of a Research Fellowship from the Medical Research (ouncil of (anada and A.J.I) is a recipient of a Research ('areer Development Award from the L:SPHS (HI) ()(0) 435$)$
Sm/IGFs (Sm-C/IGF I and IGF II) appear to play an important role in the stimulation of human fetal growth (1.2). Both peptides can be detected in human fetal serum from as early as 13 wk gestation $(1-5)$, specific receptors for each $\mathrm{Sm} / \mathrm{I}(\mathrm{GF}$ are distributed widely in human fetal tissues $(1,2)$, and both are mitogens for cultured human fetal cells $(1,2,6,7)$. Because $\mathrm{Sm} /$ IGFs appear to be synthesized in many tissues. they are thought to act at or near their sites of synthesis as paracrine or autocrine growth factors (8). Support for this in man comes from the finding that multiple human fetal tissues of 9 to $19 \mathrm{wk}$ gestation contain immunoreactive Sm-C/IGF I in far greater concentrations than can be accounted for by blood entrapment (9), and that multiple human fetal tissues of 16 to $20 \mathrm{wk}$ gestation contain mRNAs for both Sm-C/IGF I and IGF II (20).

To identify those cells where $\mathrm{Sm} / \mathrm{IGFs}$ are localized in the human fetus, we have performed immunocytochemistry on human fetal tissues and have identified cells showing positive immunoreactivity to $\mathrm{Sm} / \mathrm{IGFs}$ that are of epithelial or mesodermal origin and, in general, are differentiated.

\section{MATERIALS AND MFTHODS}

Collection and preparation of tissues. Prostaglandin-induced human fetal abortuses of 12 to $20 \mathrm{wk}$ in gestation were collected within $30 \mathrm{~min}$ of delivery after obtaining permission from the ethics committees of the respective institutions. Tissue samples $\left(1 \mathrm{~cm}^{3}\right)$ were fixed by immersion in $2 \%$ paraformaldehyde and $2 \%$ glutaraldehyde in $70 \mathrm{mM}$ phosphate buffer, pH 7.0 , at $4^{\circ} \mathrm{C}$ for 18 to $24 \mathrm{~h}$. The tissues were washed in several rinses of 0.01 $\mathrm{M}$ PBS. $\mathrm{pH}$ 7.4. over a period of 2 days, dehydrated in an ascending ethanol series $(70,90$, and $100 \%)$ and toluene. and embedded in paraffin. Tissue sections of $10-\mu \mathrm{m}$ thickness were prepared by standard techniques. mounted on slides, baked at $45^{\circ} \mathrm{C}$ for $48 \mathrm{~h}$. and stored at room temperature until processing for immunocytochemistry.

Immunociychemistry: Immunocytochemistry was performed by the avidin-biotin-peroxidase technique (10) as modified by Towle el al. (11). Briefly, tissue sections were deparaffinized in toluene. rehydrated in descending ethanol series $(100,90$, and $70 \%$ into PBS and incubated in $1 \%$ hydrogen peroxide in PBS for $15 \mathrm{~min}$ to eliminate endogenous peroxidase activity. After three additional PBS rinses. tissue sections were incubated in $0.12 \mathrm{mg} / \mathrm{ml}$ trypsin (Boehringer Mannheim Biochemicals. Indianapolis, IN) in PBS for 5 min followed by three more PBS rinses.

One of the following three primary antibodies were used: (a) a mouse ascitic fluid-derived monoclonal antibody against $\mathrm{Sm}-\mathrm{C}$ / IGF I (13.14) was used at a dilution of $1: 1000,(b)$ a rat antiserum 245 
peptide and keyhole limpet hemocyanin was used at a dilution of 1:3000, and (c) a rabbit antiserum against MSA (15) was used at a dilution of 1:1000. Sections were incubated with the antibodies in humidified chambers for $48 \mathrm{~h}$ at $4^{\circ} \mathrm{C}$. Although the monoclonal antibody raised against SM-C/IGF I was originally reported to have only $5 \%$ cross-reactivity with IGF II $(13,14)$, subsequent studies with different preparations of purified IGF II indicate that cross-reactivity is approximately $50 \%$. Cross-reactivity studies of the antiserum to MSA also indicates that it recognizes both human IGF II and Sm-C/IGF I (15). Immunocytochemistry with rabbit antisera that are highly specific for human SM-c/IGF I in radioimmunoassay (16) resulted in a negative immunostaining. Therefore, these antisera were not used in the study.

Following incubation in primary antibody, the tissue sections were rinsed in PBS, then incubated in appropriate biotinylated second antibody (Vector Laboratories, Burlingame, CA; 1:500 dilution in PBS containing $0.1 \%$ BSA) at room temperature for $2 \mathrm{~h}$. Following additional PBS rinses, tissue sections were incubated in avidin-biotin-peroxidase complex (ABC, Vector Laboratories, Burlingame $C A$ ) at room temperature for $2 \mathrm{~h}$, then rinsed again in PBS. The antibody bound peroxidase was visualized by reacting with $0.075 \%$ diaminobenzidine (Aldrich Chemical Inc., Milwaukee, WI) in Tris- $\mathrm{HCl}$ buffer, $\mathrm{pH} 7.6$, containing $0.002 \%(\mathrm{v} / \mathrm{v})$ hydrogen peroxide. Tissue sections were then counterstained with $0.05 \%$ toluidine blue, dehydrated in ascending ethanol series and xylene, and mounted with coverslips using Permount (Fisher Scientific, Springfield, NJ).

Immunospecificity studies. Several experiments were performed to verify that the antibodies used recognized Sm/IGFs specifically. There was an absence of immunostaining when preimmune or nonimmune rat or rabbit sera or nonimmune mouse ascitic fluid were substituted for the primary antibodies. Immunostaining also was not observed when antisera or immune ascitic fluid were immunoabsorbed with 1 to $10 \mu \mathrm{M}$ of partially purified preparations of either Sm-C/IGF I and IGF II (17) prior to immunostaining. Immunostaining was not altered, however, when antisera or immune ascitic fluid were incubated with 1 to $10 \mu \mathrm{M}$ concentrations of insulin, epidermal growth factor, platelet-derived growth factor and nerve growth factor. Because the antibodies were known to cross-react with both Sm/IGFs, immunoblot studies were performed with pure Sm-C/IGF I and IGF II immobilized on nitrocellulose paper (18) to determine if cross-reactivity was significant under conditions similar to those used in immunocytochemistry. At the dilutions used for immunocytochemistry, each antibody gave similar intensity of immunostaining against both peptides. Therefore, while the antibodies identified $\mathrm{Sm} / \mathrm{IGFs}$ specifically, none was capable of distinguishing between Sm-C/IGF I and IGF II.

\section{RESULTS}

Identical patterns of immunostaining were observed with each antibody in every tissue studied. Immunostained cells of at least one type were seen in all the tissues except the cerebral cortex. The proportion of immunostained cells varied among the tissues studied; the greatest proportion was observed in the liver and adrenal gland and the least in spleen and thymus. Although considerable variation in the intensity of immunostaining was observed among different cell types within the same tissue, the intensity of staining was not pronounced, suggesting that the abundance of $\mathrm{Sm} / \mathrm{IGFs}$ within the immunopositive cells was not high.

Liver. Moderate staining was observed in about $70 \%$ of the hepatocytes (Fig. $1 A$ and $B$ ). The stained and unstained hepatocytes had the same morphology, and the reason for the difference in immunoreactivity is not known. Fetal liver also contained intensely immunostained small, round nucleated hemopoietic cells with deeply basophilic nuclei. These cells, the identity of which is unclear, were observed in groups in the walls and within the lumina of the hepatic blood vessels. Similar intensely immunoreactive cells also were observed in other tissues. The mature RBCs within the blood vessels and sinusoids were unstained.

Lung. Moderate immunostaining was observed in the columnar epithelium of the primitive airways and lung fluid within the airways (Fig. $1 D$ ). The columnar epithelium of both large and small bronchioles were stained, but the intensity of staining varied among the bronchioles. No immunostaining was observed in the pleural lining and the connective tissue of the lung parenchyma.

Kidney. Moderate immunostaining was seen in the lining columnar epithelium of the proximal and distal convoluted tubules, and weak staining was observed in the collecting ducts (Fig. $1 F)$. No immunostaining was observed in the capsule, tubules of the nephrogenic zone, loops of Henle, connective tissue parenchyma, or glomeruli.

Adrenal. About $60 \%$ of the parenchymal cells in the mature adrenal cortex were immunostained, but the fetal zone of the cortex, and the medulla contained no immunoreactive cells (Fig. $1 \mathrm{H})$.

Pancreas. In 12- to 15-wk fetuses (when the islet cells have not yet organized), positive immunostaining was observed in the epithelial cells, the presumptive progenitor cells of the exocrine, or endocrine pancreas. In the older fetuses, staining predominated in the islets and was minimal in the exocrine pancreas.

Stomach and small intestine. Throughout the gastrointestinal tract, only the epithelial cells of the mucosa showed positive staining (Fig. 1G). The columnar cells that lined the villi of the intestine stained more intensely than cells lining the crypts.

Thymus and spleen. Groups of immunostained cells having the morphology of immature henopoietic precursors were observed in the corpuscles and interlobular septa of the thymus and were distributed widely in the parenchyma of the spleen. Most lymphoid cells in the thymic lobules and splenic corpuscles showed no immunostaining.

Skeletal and cardiac muscle. Moderate immunostaining was observed in the fibers of both skeletal (Fig. $1 E$ ) and cardiac muscles, but none was seen in the fibrous sheaths and septa.

Skin. Skin from the anterior abdominal wall showed minimal immunostaining in the stratum granulosum of the epidermis and moderate staining of the deep layers of the dermis (Fig. $1 I$ ). No immunostaining was observed in the adnexae of the skin, including hair follicles and sweat glands.

\section{DISCUSSION}

Using immunocytochemistry, we have shown that multiple tissues from 12- to 20-wk human fetuses contain cells with $\mathrm{Sm} /$ IGF immunoreactivity. Because the antibodies used in this study recognize both Sm-C/IGF I and IGF II, identification of specific $\mathrm{Sm} /$ IGFs was precluded. Negative immunostaining with an antiserum which is highly specific for $\mathrm{Sm}-\mathrm{C} / \mathrm{IGF} \mathrm{I}$ in radioimmunoassay (15), however, suggests that the immunoreactivity may be attributed predominantly to IGF II. Both SM-C/IGF I and IGF II peptides are probably present in multiple fetal tissues, however, because (a) immunoassayable Sm-C/IGF I is readily detected with a highly specific antibody in extracts of many tissues obtained from human fetuses during the first half of pregnancy (9), (b) specific Sm-C/IGF I and IGF II mRNAs are present in many human fetal tissues of similar gestation (20) (Han VKM, Lund PK, D'Ercole AJ, unpublished observations), and (c) Sm/IGF mRNAs can be localized to fibroblasts and mesenchymal cells by in situ hybridization histochemistry using specific oligodeoxyribonucleotide probes to non-homologous regions of both Sm-C/IGF I and IGF II mRNAs (20).

Bennington et al. (18) have reported the localization of Sm$\mathrm{C} / \mathrm{IGF} \mathrm{I}$ in human fetal and adult tissues by an immunoperoxidase technique using a rabbit antiserum to human Sm-C/IGF I. Although a detailed description is lacking, the distribution of 


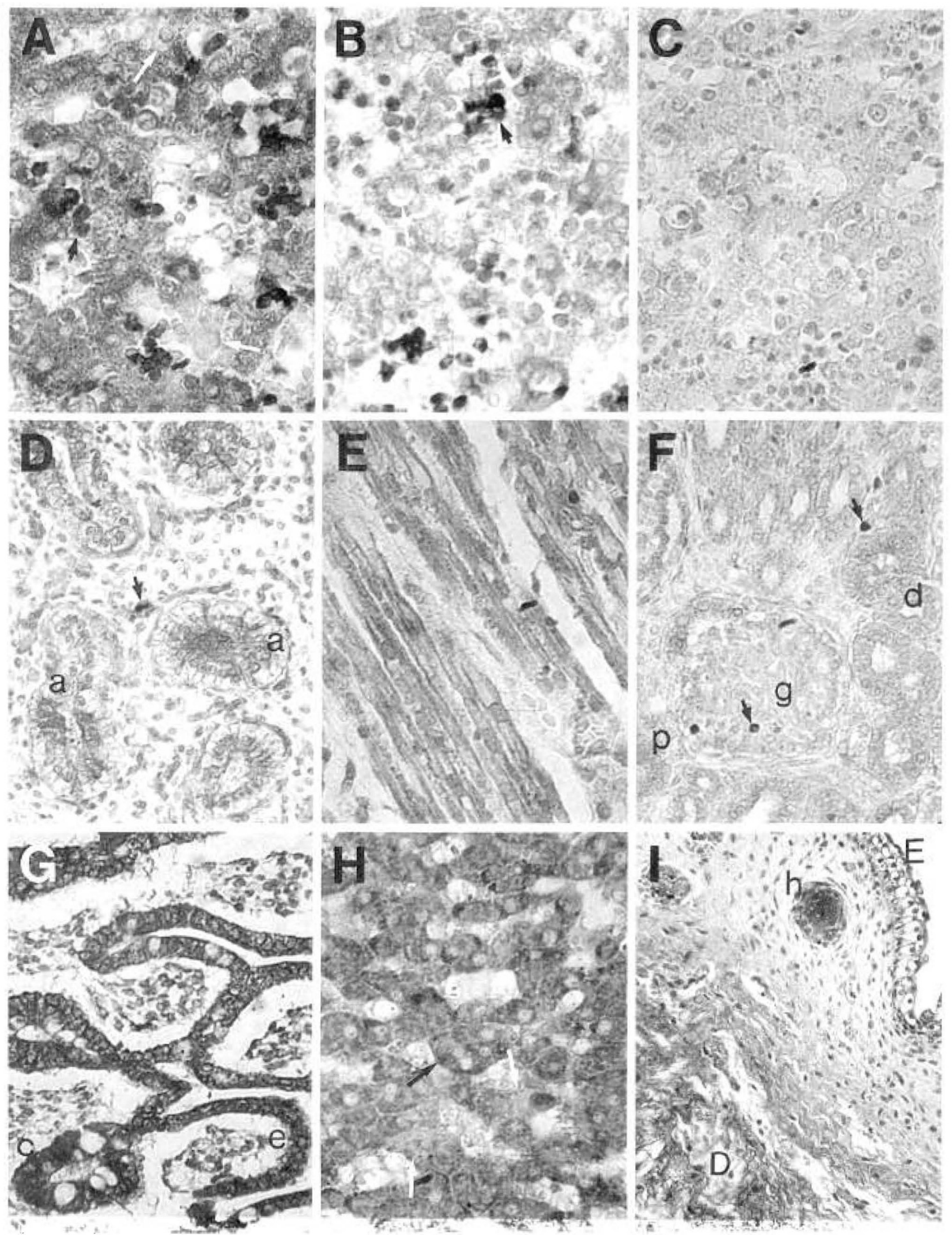

Fig. 1. Photomicrographs of human fetal tissues immunostained with antibodies against $\mathrm{Sm} / \mathrm{l}$ (ifs by the avidin-biotin peroxidase technicue, using diaminobenzidine as a color agent. 1. human fetal liver mmunostained with Sm 1.2. a monoctonal antibody raised against Sm-( $/ 1$ (if I: the white arrous point to unstained hepatocstes. the smoll dark arrew points to an intensely stained hemopoietic eell. B. human fetal liver. inmunestained with an antiscrum against IC iF II e-peptide; arrows, same as . . (; human fetal liver, immunostained with a preimmune nude mouse ascitic tluid (similar results were obtained with preimmune and nonimmune rabbit and rat antisera. and following immunoabsorption of antibodics with $1-10$ $\mu \mathrm{M} \mathrm{Sm} / \mathrm{l}$ (ifs). I) to (i. human fetal tissues immunostained with Sm 1.2. D). I ung. a. primitive airway filled with fetal lung fluid: the arrow points to an immunopositive hemopoictic cell. F. Skeletal muscle. $l$. Kidney. g. glomerulus: p. proximal convoluted tubule: $d$. distai consoluted tubule: the arrows point to hemopoietic cells. ( $r$. intestine. e. columnar epithelium of a villous: $c$. columnar epithelium of a crypt of 1 ieberh uhn. $H$. adrenal. ( $\therefore$ adrenal cortical ecils: the dark arrow points to a stained cell and the white arrows point to unstained cells. $I$. Shin. $l$. epidermis: $l$ ). dermis: $h$. hair follicle. 
Sm-C/IGF I immunoreactive cells appears to be similar to that in our study. Similarly, Andersson et al. (19) recently reported identification of Sm-C/IGF I immunoreactive cells in several tissues from adult rats. Although their antibodies differ in specificity from ours, and the species and ages of the animals studied are also different, the findings in the two studies are similar.

One interpretation of our findings and those of others is that immunostaining identifies $\mathrm{Sm} / \mathrm{IGF}$ synthesizing cells that are dispersed widely in many tissues. We believe that such a conclusion may be erroneous, because immunocytochemical techniques only identify the cellular location of peptides possessing specific antigenic determinants; such techniques do not indicate whether an immunostained cell is a site of synthesis of the antigen or whether it has accumulated the antigen from another source. Using in situ hybridization histochemistry with specific oligodeoxyribonucleotide probes for mRNAs encoding Sm-C/IGF I and IGF II, we have observed that Sm/IGF transcripts in human fetal tissues are localized predominantly in fibroblastic and mesenchymal cells (20). In general, these $\mathrm{Sm} / \mathrm{IGF}$ mRNAs are localized to connective tissue elements such as organ capsules and septa. Furthermore, most of the immunopositive cells observed in the present study did not possess Sm/IGF mRNAs in significant abundance to be identified by in situ hybridization. While this lack of concordance among cells identified by the two techniques suggests that most of the immunostained cells do not synthesize Sm/lGFs, it is possible that the mRNAs of some fetal cells are unstable, are not translated, or result in production of a peptide form that is not recognized by the antibodies used. On the other hand, immunostained cell may have sequestered Sm/ IGF from other sources by cell surface binding with subsequent internalization (21) and sequestration in endoplasmic reticulum, as has been shown for vascular endothelium (22). Moreover, the immunoreactive cells may be sites of degradation of the peptides. Regardless of the mechanisms involved, the immunolocalization of $\mathrm{Sm} / \mathrm{IGF}$ to specific cells in vivo is likely to have physiologic significance.

The observation that fibroblasts, which are rich in $\mathrm{Sm} / \mathrm{IGF}$ mRNA and are capable of $\mathrm{Sm} / \mathrm{IGF}$ synthesis in culture (23-25), usually exhibit no immunostaining suggests that these cells have little capacity to store $\mathrm{Sm} / \mathrm{IGFs}$. A paucity of intracellular storage is supported by the delay of 4 to $8 \mathrm{~h}$ in a rise of Sm-C/IGF I in tissues and plasma following the injection of $\mathrm{GH}$ into hypophysectomized rats (8) and a similar delay when $\mathrm{GH}$ is administered in man $(26,27)$. In contrast, cultured human fetal hepatocytes appear to store $\mathrm{Sm} / \mathrm{IGFs}$ since they immunostain for these peptides (28). This Sm/IGF is released from both rat and human isolated fetal hepatocytes under hormonal control $(28,29)$. It is not yet known whether the Sm/IGF present and released is due to sequestration or de novo synthesis.

In most of the tissues we examined, the connective tissue cells that possess Sm/IGF mRNAs are near the cells that exhibit Sm/ IGF immunoreactivity. This juxtaposition of cells that synthesize $\mathrm{Sm} / \mathrm{IGFs}$ with those that may respond to $\mathrm{Sm} / \mathrm{IGFs}$ supports the paracrine hypothesis of action of these peptides. The dermis (and possibly adrenal cortex) may be an exception, because in this tissue immunostaining and in situ hybridization occur in the same cells. If this is the case, an autocrine mechanism of growth control could be operative $(30,31)$. The observation that $\mathrm{Sm} /$ IGF immunoreactivity is prominent in differentiated cells support the concept that these peptides are important mediators of differentiated cell functions (30-33), as well as proliferation.

The results of the present study can be interpreted in a number of ways. We believe, however, that these immunolocalization studies indicate sites where $\mathrm{Sm} / \mathrm{IGFs}$ are accumulated and/or act given the evidence from in situ hybridization histochemistry that most of the immunostained cells are not the major sites of $\mathrm{Sm} / \mathrm{IGF}$ gene expression. Large et al. (34) found markedly different abundances of NGF and its mRNA in different brain regions. Although these alterations in relative abundance may be explained by neuronal retrograde transport of NGF through axons, it seems possible that other mechanisms, such as those we have postulated, may be responsible for the discrepancies in $\mathrm{Sm} / \mathrm{IGF}$ immunolocalization and in situ hybridization histochemistry that we have observed.

Acknowledgments. The authors thank the staff of the gynecologial units of the Northern General Hospital and the North Carolina Memorial Hospital, and Dr. F. Askin, Department of Pathology, U.N.C., for their help in collection of fetal tissues, Dr. Peter Nissley for his kind gift of antiserum to MSA, and Ms. H. Hearn and Mrs. J. Higgingbottom for their technical assistance.

\section{REFERENCES}

1. D'Ercole AJ, Underwood LE 1981 Growth factors in fetal growth and development. In: Novy MJ, Resko JA (eds) Fetal endocrinology: ORPC Symposia on Reproductive Biology, vol 1. Academic Press, New York, pp 155-182

2. Underwood LE, D'Ercole AJ 1984 Insulin and insulin-like growth factors/ somatomedins in fetal and neonatal development. Clin Endocrinol Metabol 13.1:69-89

3. Bennett A, Wilson DM, Liu F, Nagashima R, Rosenfeld RG, Hintz RL 1983 Levels of insulin-like growth factors I and II in human cord blood. $\mathrm{J}$ Clin Endocrinol Metabol 57:609-612

4. Gluckman PD, Johnson-Barrett JJ, Butler JH, Edgar BW, Gunn TR 1983 Studies of insulin-like growth factor I and II by specific radioligand assays in umbilical cord blood. Clin Endocrinol 19:405-413

5. Ashton IK, Zapf J, Einschenk I, MacKenzie IZ 1985 Insulin-like growth factors (IGF) I and II in human foetal plasma and relationship to gestational age and foetal size during mid-pregnancy. Acta Endocrinol 1 10:558-563

6. Hill DJ, Crace CJ, Strain AJ, Milner RDG 1986 Regulation of amino acid uptake and DNA synthesis in isolated human fetal fibroblasts and myoblasts: Effect of human placental lactogen, somatomedin-C, multiplication-stimulating activity and insulin. J Clin Endocrinol Metabol 62:753-760

7. Hill DJ, Crace CJ, Milner RDG 1985 Incorporation of $\left[{ }^{3} \mathrm{H}\right]$ thymidine by isolated human fetal myoblast and fibroblasts in response to human placental lactogen (HPL): possible mediation of HPL action by release of immunoreactive somatomedin-C. J Cell Physiol 125:337-344

8. D'Ercole AJ, Stiles AD, Underwood LE 1984 Tissue concentrations of somatomedin-C: further evidence for multiple sites of synthesis and paracrine/ autocrine mechanisms of action. Proc Natl Acad Sci USA 81:935-939

9. D'Ercole AJ, Hill DJ, Strain AJ, Underwood LE 1986 Tissue and plasma somatomedin-C/insulin-like growth factor I ( $\mathrm{Sm}-\mathrm{C} / \mathrm{IGF}$ ) concentrations in the human fetus during the first half of gestation. Pediatr Res 20:253-255

10. Hsu SM, Raine L, Fanger H 1981 Use of avidin-biotin peroxidase complex $(\mathrm{ABC})$ in immunoperoxidase techniques: a comparison between $\mathrm{ABC}$ and unlabeled antibody (PAP) procedures. J Histochem Cytochem 29:577-580

11. Towle AC, Lauder JM, Joh TH 1984 Optimization of tyrosine hydroxylase immunocytochemistry in paraffin sections using pretreatment with proteolytic enzymes. J Histochem Cytochem 32:766-770

12. Russell WE, Van Wyk JJ, Pledger WJ 1984 Inhibition of the mitogenic effects of plasma by a monoclonal antibody to somatomedin-C. Proc Natl Acad Sci USA 81:2389-2392

13. Gillespie GY, Van Wyk JJ, Underwood LE, Svoboda ME 1986 Derivation of monoclonal antibodies to somatomedin-C/insulin-like growth factor I. In: Barnes D, Sirbasku D (eds), Methods in Enzymology, Peptide Growth Factors, Academic Press, Orlando, FL (in press)

14. Moses AC, Nissley SP, Short PA, Rechler MM 1980 Immunological crossreactivity of multiplication stimulating activity polypeptides. Eur J Biochem 103:401-408

15. Furlanetto RW, Underwood LE, Van Wyk JJ 1977 Estimation of somatomedin-C levels in normals and patients with pituitary disease by radioimmunoassay. J Clin Invest 60:648-657

16. Svoboda ME, Van Wyk JJ, Klapper DG, Fellows RE, Grissom FE, Schleuter RJ 1980 Purification of somatomedin-C from human plasma: chemical and biological properties, partial sequence analysis and relationship to other somatomedins. Biochemistry 19:790-797

17. Tobin H, Stachelin T, Gordon J 1979 Electrophoretic transfer of proteins from polyacrylamide gels to nitrocellulose sheets: procedure and some practical applications. Proc Natl Acad Sci USA 76:4350-4354

18. Bennington J, Spencer EM, Reber K 1983 Immunoperoxidase localization of insulin-like growth factor I containing tissues. In: Spencer EM (ed) InsulinLike Growth Factors, Somatomedins: Basic Chemistry, Biology and Clinical Importance. Walter de Gruyter, Berlin, pp 563-570

19. Andersson I, Billig H, Fryklund L, Hansson HA, Isaksson O, Isgaard J, Nilsson A, Rozell B, Skotnner A, Stemme S 1986 Localization of IGF-I in adult rats. Immunohistochemical studies. Acta Physiol Scand 126:311-312

20. Han VKM, D'Ercole AJ, Lund PK Cellular localization of somatomedin (insulin-like growth factor) messenger RNA in the human fetus. Science 236:193-197

21. Frank HJL, Partridge WM, Morris WL, Rosenfeld RG 1985 Binding and internalization of insulin and insulin-like growth factor Il (IGF II) but not IGF I by brain capillaries. Diabetes 34(supp1 1:)58(abstr)

22. Bar RS, Boes M, Yorek M 1986 Processing of insulin-like growth factors I and II by capillary and large vessel endothelial cells. Endocrinol 118:1072-1080 
23. Atkison PR. Weidman FR, Bhaumick B, Bala RM (1980) Release of somatomedin-like activity by cultured W1-38 human tibroblasts. Fndocrinology $106: 20(0)(6-20 ! 2$

24. Clemmons DR. Underwood I.I: Van Wyk JJ 1981 Hormonal control of immunoreactive somatomedin production by cultured human fibroblasts. J (lin Invest 67:10-19)

25. Adams S(). Nissley SP. Handwerger S. Rechler MM 1983 I Developmental patterns of insulin-like factor I and II synthesis and regulation in rat fibroblasts. Nature 302:150-153

26. ("opeland KC'. Underwood I.F., Van Wyk JJ 1980) Induction of immunoreactive somatomedin-( $C^{\prime}$ in human serum by growth hormone: dose response relationships and effect on chromatographic profiles. J (lin Endocrinol Metab 50:690)-697

27. Dean HJ, Kellet JC; Bala RM. (juyda IHJ, Bhaumick B. Posner BI, Friesen HIF 1982 The effect of growth hormone treatment on somatomedin levels in growth hormone deficient children. J Clin Endocrinol Metabol 55.1167 1173

28. Strain AJ, Hill I)J, Swenne I. Milner RIX) (1987) The regulation of DNA in human fetal hepatecytes by placental laciogen, growth hormone and insulin- like growth factor $\mathrm{V} / \mathrm{somatomedin-(} \mathrm{I} \mathrm{(c)ll} \mathrm{Phosiol} \mathrm{(in} \mathrm{press)}$

29. Richman RA. Benediet MR. Florini JR. Toly BA 1985 Iformonal regulation of somatomedin secretion by fetal rat hepatocytes in primary culture. Indocrinology: $116: 180-188$

30. ("emmons J)R. Van Wuk Jj 198! Somatomedin: Phusiological control and effects on cell proliferation. In: Bascrga $R$ (ed) Tissue (irowth factors. Iandbook of Experimental Phamacology, Vol 57. Springer-Verlag. Berlin, pp $16:-208$

31. Conover (A. Rosenfeld RF: Hintz RI. 1986 Hormonal control of the replicaton of human fetal fibroblasts: role of somatomedin- ${ }^{\circ}$ /insulin-like grouth factor I. J (cell Physiol 128:47-54

32. Adashi EY, Resnick (Y: Sroboda ME Van Wyk JJ 1984 a nowel role for somatomedin- $\left({ }^{\prime}\right.$ in the cytodifferentiation of the ovarian granulosa cell. Fndocrinology $115: 1227-1229$

33. Ewton DZ. Florini JR 1981 Fiffects of somatomedins and insulin on moblast differentiation in vitres. Dex Biol $86 \cdot 31-36$

34. Large TH. Bodary SC. (legg I)O. Weskamp (i. Otten 1., Recichardt 11: 1986 Nerve growth factor gene expression in the devetoping rat brain. Science $234: 352-355$

\section{Announcement}

\section{Nineteenth International congress of Pediatrics}

The Congress will take place on July 23 to 28,1989 in Paris. France. Organizer: Professor Jean Frézal. Host: Societe Française de Pédiatrie. Sponsorship: International Pediatric Association. Languages: French. English. and Spanish.

For information comat: PMV Congres. 130). rue de (lignancourt. 75018 Paris. France. Telex: 640 $847 \mathrm{~F}$ 